\title{
Effects of in ovo injection of amino acids on hatching performance, cell-mediated immunity and blood profile of FUNAAB Alpha broiler chickens
}

\author{
*Sogunle, O. M., 'Olutayo, A. J., Odutayo, O. J., ${ }^{2}$ Oso, O. A., ${ }^{3}$ Sobukola, O. P., Safiyu, K. \\ K. and ${ }^{4}$ Elangovan, A. V. \\ Department of Animal Production and Health, Federal University of Agriculture, \\ Abeokuta, P. M. B. 2240, Abeokuta, Ogun State, Nigeria \\ ${ }^{1}$ Livestock Science and Sustainable Environment, World Bank Centre of Excellence in \\ Agricultural Development and Sustainable Environment, Federal University of \\ Agriculture, Abeokuta \\ ${ }^{2}$ Department of Animal Nutrition, Federal University of Agriculture, Abeokuta, P. M. B. \\ 2240, Abeokuta, Ogun State, Nigeria \\ ${ }^{3}$ Department of Food Science and Technology, Federal University of Agriculture, \\ Abeokuta, P. M. B. 2240, Abeokuta, Ogun State, Nigeria

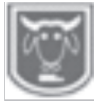 \\ ${ }^{5}$ India Council of Agricultural Research-National Institute of Animal \\ Nutrition and Physiology, (ICAR-NIANP), Bengaluru, India \\ Abstract \\ *Correspondence author: sogunleom@funaab.edu.ng
}

In the study, the effects of in ovo injection of amino acids (L-methionine, L-lysine, and Larginine) and their combinations on hatching traits, post-hatch performance, cell-mediated immune response and blood profile of FUNAAB Alpha broiler chicken were evaluated. The study was carried out in two trials. In the first trial, a total of 360 hatching eggs of indigenous chicken were fumigated, weighed and placed in the incubator. On day 14 of incubation, candling was done and eggs with living embryos were distributed into four treatments; Control (un-injected eggs), L-methionine injected eggs, L-arginine injected eggs and Llysine injected eggs. Each egg was injected $0.5 \mathrm{~mL}$ solution of the amino acid on dayl8. Hatched chicks were distributed into three replicates containing 30 chicks each. In trial 2, another 360 hatching eggs were used in the treatments which were; Control (eggs without amino acid injection), L-arginine injected eggs, combination of L-arginine and Lmethionine injected eggs and combination of L-arginine and L-lysine injected eggs. On day 21 post-hatch, cell-mediated immune response, haematological and serum biochemical parameters were determined. Data obtained from the two trials were subjected to Completely Randomized Design. Results revealed the highest hatchability of $70.27 \%$ in the control treatment (un-injected), followed by $51.35 \%$ in arginine-injected eggs with the lowest $(2.70 \%)$ in methionine-injected eggs. Arginine was found to enhance hatchability while L-methionine injected in ovo decreased hatchability. In the second trial, the results showed highest hatchability (89.58\%) in eggs under the control, followed by 39.29\%, $30.80 \%$ and $21.43 \%$ in eggs injected with the combination of arginine and lysine, arginine injected eggs, and those with arginine and methionine combination, respectively. Significant $(p<0.05)$ differences in growth performance were only observed in the feed conversion ratio and percentage survivability. Better feed conversion ratio of 2.18 and 2.29 were recorded in birds injected with arginine and the control as against those subjected to combined arginine and methionine (2.96) as well as combined arginine and lysine (3.12). Survivability of 100\% was recorded in chickens from arginine-injected eggs in ovo injection and chickens from eggs injected with the combination of arginine and methionine. The study concluded that in ovo injection of arginine either singly or in combination with lysine or methionine positively influenced hatchability, chick weight and growth performance without any deleterious effect 
on the blood profile of the post-hatch chicks.

Keywords: L-arginine, L-methionine, L-lysine, Cell-mediated Immunity, Blood profile, Duodenal histology, Indigenous Chicken

\section{Introduction}

There is a growing concern on how the genetic resources of indigenous chickens can be improved for better performance. The indigenous chickens are commonly found in developing countries including Nigeria and they play a vital role in many rural households. However, productivity of these chickens is low, thus they produce few eggs which have low hatchability (Safalaoh, 2001). Although, they are mostly raised on free range or in some cases on semi-intensive system of management, their production does not commensurate the investment. Poor nutrition plays an important role in all these problems and thus, the production potential of these breeds cannot be realized without supplying them with required nutrients. This contributes to low income and poor nutrition for rural poor resource farmers. FUNAAB Alpha broiler chicken was developed as an improvement over the indigenous chickens by a foremost scientist in the field of Animal Breeding and Genetics, Federal University of Agriculture, Abeokuta, Nigeria.

Nutrition is a crucial growth performance component that can be manipulated in order to improve poultry production. Several strategies on nutrition have been looked into in order to achieve economic and better performance in poultry production. One of such nutritional strategies is in ovo feeding of exogenous material which was first carried out in 1980s, with vaccination of poultry against Marek's disease (Sharma and Burmester, 1982). In ovo feeding is a technology that gives hatchlings a nutritional benefit as a means of introducing nutrients into developing embryo (Uni and Ferket, 2003). Among several importance of in ovo feeding from previous reports include; better efficiency of feed utilization (Bhanja et al., 2004); reduce post-hatch mortality and morbidity; improved immune response (Gore and Quereshi, 1997); enhanced early growth by improving intestinal function and development by enhancing absorption by the villi (Tako et al., 2004; Noy and Uni, 2010); increased skeletal growth and breast muscle yield (Hajihosaini and Mottaghitalab, 2004), marketing body weight (Selim et al., 2012) and improved hatchability (Sogunle et al., 2018). Different nutrients are used for in ovo feeding including amino acids to promote growth, immune and gut functions. Methionine is involved in the metabolic processes that improve health, growth, development and reproduction in animals. Being the first limiting amino acid in poultry diets, methionine affects poultry production (Jankowski et al., 2014). Dietary methionine supplementation to broiler diets improved feed efficiency and body weight gain (Maatman et al., 1993); increased carcass yield (Schuttle et al., 1997); and live weight gain (Safaei et al., 2012). Lysine as well contribute to the synthesis of body proteins and peptides, which are indispensable organic compounds participating in all biochemical reactions and physiological activities, including structural support of living cells and tissues. Khajali and Wideman (2010) opined that arginine serves as substrate for the biosynthesis of several molecules, including protein, nitric oxide, creatine, ornithine, glutamate, polyamines, proline, g l u t a mine, a g m a tin e and dimethylargininese thereby playing a vital biological and physiological function in poultry. Also the inclusion of arginine in poultry diets is essential in order to keep the 


\section{Sogunle, Olutayo, Odutayo, Oso, Sobukola, Safiyu and Elangovan}

birds away from the harmful influences of free radicals produced during normal metabolism (Atakisi et al., 2009). These nutrients are supplemented to the developing embryo through the amniotic sac at the $18^{\text {th }}$ day of incubation, to provide a continuous supply of critical nutrients during the first few days after hatching, and thereafter help in enteric development and metabolism process. Supplementing the amnion fluid with nutrients by the process of in ovo injection of amino acids (proteins) will go in long way to correct inadequacies in poultry diets, positively affect hatching eggs nutrients status and enhance the overall performance of the resulting chicks. This study therefore determined the effects of in ovo feeding of amino acids on hatching, post-hatching performance, cellmediated immune response, and blood profile of indigenous chickens.

\section{Materials and methods \\ Experimental location}

The study was composed of two trials as described; In ovo injection of DLmethionine, L-lysine, L-arginine and their combination in hatching eggs of improved indigenous chicken and In ovo injection of L-arginine, combined L-arginine and DLmethionine; combined L- arginine and Llysine.

The hatchery study was carried out using the Incubator of the College of Animal Science and Livestock Production. The field experiment was undertaken at the Poultry unit of the Teaching and Research Farm of the University while the laboratory study was carried out at the Animal Products and Processing Laboratory of the Department of Animal Production and Health, Federal University of Agriculture, Abeokuta, Ogun State, Nigeria.

Source of fertile eggs of indigenous chicken

A total of 360 hatching eggs of indigenous chickens sourced from the Teaching and
Research Farm, Federal University of Agriculture, Abeokuta was used at each trial.

Management of the fertile eggs at the hatchery

The 360 hatching eggs were handled carefully and store at room temperature, they were weighed individually before being transferred to the setting compartment. These hatching eggs were divided into four treatments (90 eggs per treatment) groups at each trial. Each treatment is replicate three times. Description of the treatment group for the separate trial is represented as follows:

In ovo injection for trial 1 was composed of the following treatment groups: Control (un-injected), L-arginine (25 mg/egg), Lmethionine $(10 \mathrm{mg} / \mathrm{egg})$ and L-lysine (22 $\mathrm{mg} / \mathrm{egg}$ ). In trial 2, the following treatment groups were used: Control (un-injected), Larginine $(25 \mathrm{mg})$, Combined L-arginine and L-methionine $(25 \mathrm{mg}+10 \mathrm{mg} / \mathrm{egg})$ and Combined L-arginine and L-lysine $(25 \mathrm{mg}$ + $22 \mathrm{mg} / \mathrm{egg}$ ). To avoid contamination, the eggs were fumigated with potassium tetraoxo-manganate VII $\left(\mathrm{KMNO}_{4}\right)$ and formaldehyde in the ratio 1:2 in an enclosed chamber for just 20 minutes. Thereafter, the eggs were placed inside an incubator and managed (with the appropriate temperature, relative humidity and turned automatically on hourly basis) for 18 days.

\section{Preparation of amino acids solution for in ovo injection}

A total of $10 \mathrm{mg}$ of methionine, $22 \mathrm{mg}$ lysine and $25 \mathrm{mg}$ of arginine were dissolved in $0.5 \mathrm{~mL}$ of deionised water as described by Bhanja etal. (2012).

Procedure for in ovo amino acids injection At 14 days of incubation, the 360 eggs were checked for fertility by candling and the dead embryos were equally removed from the incubator. The eggs with living embryo were redistributed into four treatments groups as described above. At day 18 of incubation, the broad end of each egg was 
cleaned with mild disinfectant $(30 \%$ ethanol) and a pinhole was made on the broad end of the egg. Thereafter, $0.5 \mathrm{~mL}$ of the amino acid solutions were injected into the egg with a 24-gauge hypodermic needle (11 mm long) (Bhanja et al., 2004). The holes were sealed up with sterile paraffin and the eggs were returned into the incubator. The exercise was completed within 30 minutes of taking out of eggs from the incubator. The injected eggs including the eggs on control treatment were then transferred to hatching compartment. Proper monitoring of the incubator conditions was done.

\section{Post-hatched chicks}

The chicks that were hatched on day 21 of incubation, were weighed to evaluate the effect of in ovo injection of the amino acids. They were distributed into the four treatments, replicated three times with equal number of chicks per replicate. They were managed intensively in deep litter with the provision of feed (Table 1) and water ad libitum.

\section{Data collection}

Data were collected on the hatching traits which included egg weight, percentage hatchability, chick weight, chick to egg ratio and embryonic mortality. The feed intake, weight gain and mortality were recorded daily while the feed conversion ratio was calculated.

\section{Histology of the duodenum}

A segment of the duodenum from the proximal and distal parts of the ampulla was selected from two birds slaughtered by cervical dislocation at age 7 days of the study in trial 2 . The thin parts were collected from five regions: proximal, proxo-middle, middle, mid-distal and distal. The samples were fixed in $4 \%$ paraformaldehyde in PBS for 30 to 40 hours at room temperature for routine histological techniques. After fixation, the specimens were dehydrated in ascending grades of alcohol, cleared in xylene and embedded in paraffin wax as blocks as described by Althnaian et al. (2013)

Table 1: Composition (\%) of the experimental diets

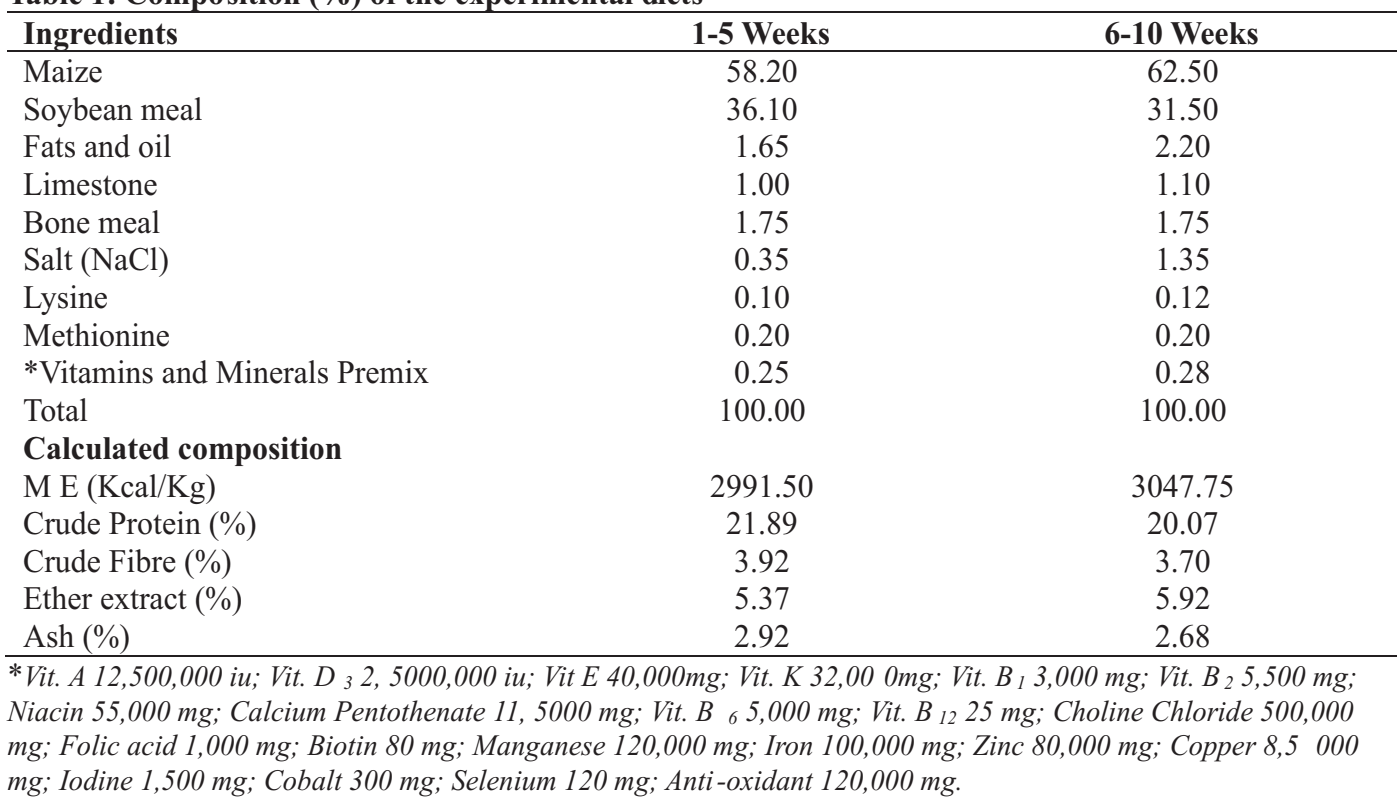




\section{Sogunle, Olutayo, Odutayo, Oso, Sobukola, Safiyu and Elangovan}

\section{Cell-mediated immune response}

Cell-mediated immunity was carried out at day 21 post-hatch. The reagent used was: Phosphate buffer saline (PBS); Sodium chloride, 8.0 g: Potassium chloride, $0.20 \mathrm{~g}$ : Potassium dihydrogen phosphate, $0.20 \mathrm{~g}$; Disodium hydrogen phosphate. $1.44 \mathrm{~g}$; distilled water, 1 litre; $\mathrm{pH}$ of 7.2. The method of Corrier and Deloach (1990) was used which shows the response of cellmediated immune to phytohemagglutinin type P (PHA-P). At 21 days post-hatch, $0.1 \mathrm{ml}$ (concentration $1 \mathrm{mg} / \mathrm{ml}$ ) of PHA-P was injected at both the third and fourth inter-digital space of the right foot of the sampled bird. While the left foot which serve as control was injected with $0.1 \mathrm{ml}$ of phosphate buffer saline (PBS). The foot web index was calculated as the difference between the swelling in the right and left feet before and after 24 hours of injection and expressed as millimetre.

Cell-mediated immune response $(\mathrm{CMIR})=$ (R2-R1)-(L2-L1)

$\mathrm{R} 2=$ Thickness of right foot web after 24 hours of injection

$\mathrm{R} 1=$ Thickness of the right foot web before injection.

L2 $=$ Thickness of left foot web after 24 hours of injection

L1 = Thickness of the left foot web before injection

Determination of haematological parameters and serum biochemical indices

On day 21 of trial 2, $5 \mathrm{~mL}$ of blood were collected from the brachial vein of 3 selected birds per replicate into Ethylene Diamine Tetra acetic acid (EDTA) tubes. All samples were collected in the morning before feeding (between 07:00 am to 09:00 am). Blood samples collected were kept in cool containers and transported to the laboratory within 2 hours of blood withdrawal. Haematological parameters measured were analyzed according to the procedures described by Sood (2016).
Packed Cell Volume (PCV) was determined using microhaematocrit capillaries. Haemoglobin concentration (Hb) was determined using cyanmethaemoglobin method which involves mixing $5 \mathrm{~mL}$ of Drabkin's solution $(1000 \mathrm{~mL}$ of deionised water was mixed with $400 \mathrm{mg}$ of Potassium ferricyanide, $280 \mathrm{mg}$ of Potassium dihydrogen phosphate, $100 \mathrm{mg}$ of Potassium cyanide and $1 \mathrm{~mL}$ of non-ionic detergent) with $20 \mu \mathrm{l}$ of blood sample. The mixture was read in a photocolorimeter at $540 \mathrm{~nm}$ (green filter). Blood counts were determined using the improved Neubauer's chamber (area of $9 \mathrm{sq} / \mathrm{mm}$ and depth of 0.1 $\mathrm{mm})$. Platelet count was determined using Rees-Ecker method using a diluting fluid that consist of $3.8 \mathrm{gm}$ of Trisodium citrate, $0.2 \mathrm{ml}$ of Neutral formaldehyde, $0.1 \mathrm{gm}$ of Brilliant cresyl blue and $100 \mathrm{~mL}$ of Deionised water.

Serum biochemical parameters (total protein, albumin, globulin, creatinine, Alanine transaminase (ALT) and Aspartate transaminase (AST), uric acid, cholesterol, triglycerides) were analyzed using commercially available test kits by Randox laboratories, United Kingdom (Model BT294QY).

\section{Experimental design}

The experiments were laid out in a Completely Randomized Design.

\section{Statistical analysis}

Data were subjected to Analysis of Variance. Significantly $(\mathrm{P}<0.05)$ different means among variables were separated using Tukey as contained in Minitab (2013) version 17.1.0.

\section{Results}

Figure 1 shows the effect of in ovo injection of amino acids on hatching traits of indigenous chickens for trial 1 . The highest hatchability of $70.27 \%$ was obtained in hatching eggs of indigenous chicken in the control treatment followed by hatching egg subjected to arginine in ovo injection (51.35 
$\%$ ), while the lowest hatchability percentage of 2.70 was observed from hatching eggs of indigenous chicken under methionine in ovo injection. Highest chick weight (39.31g) was recorded in chicks hatched in the control treatment group while the lowest chick weight of $31 \mathrm{~g}$ was obtained from chicks injected with methionine. The numerically highest chick to egg ratio of 0.70 was recorded in hatching eggs injected with lysine while the lowest $(0.54)$ chick to egg ratio was noted in hatching eggs of indigenous chickens under methionine injection. Figure 2 shows the effect of in ovo injection of arginine, its combination with methionine and lysine on hatching traits of indigenous chickens for trial 2. Hatchability was highest (89.58\%) in eggs on the control treatment followed by $39.29 \%$ in eggs injected with the combination of arginine and lysine, and the lowest hatchability $(28.57 \%)$ was recorded in eggs injected with the combination of arginine and methionine.
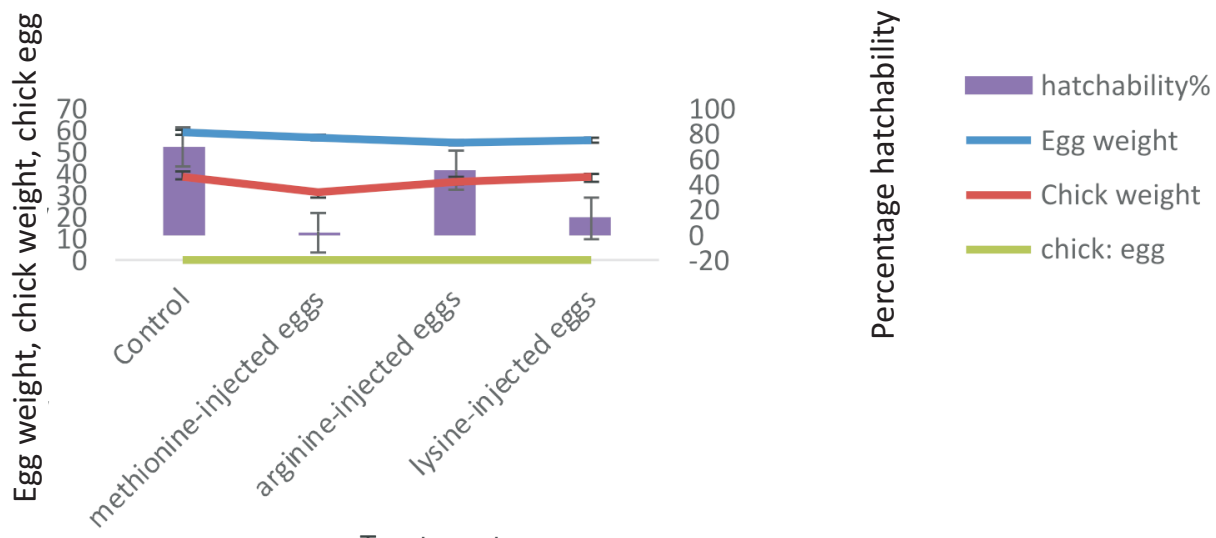

Treatment

Fig. 1: Effect of in ovo injection of methionine, arginine and lysine on hatching traits of FUNAAB Alpha broiler chickens

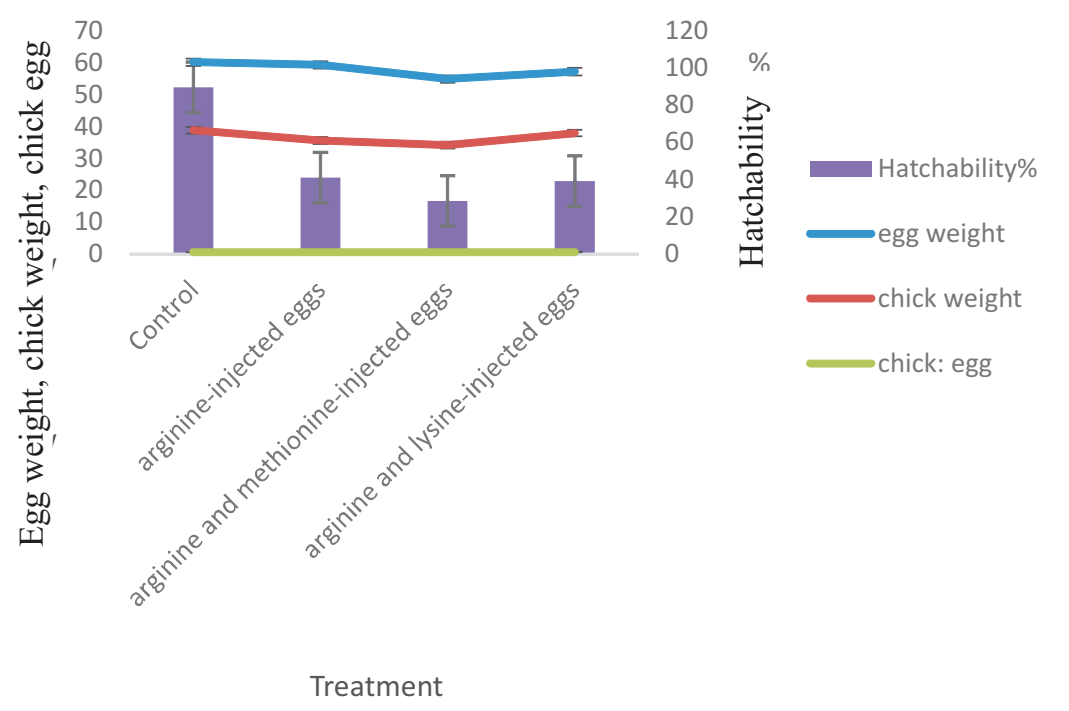

Fig. 2: Effect of in ovo injection of arginine, its combination with methionine and lysine on hatching traits of FUNAAB Alpha broiler chickens 
Table 2 shows the effects of in ovo injection of amino acids on the growth performance of indigenous chickens. Significant $(p<0.05)$ differences were observed in the feed conversion ratio and percentage survivability. Better feed conversion ratios of 2.18 and 2.29 were recorded in birds injected with arginine and the control as against the value obtained in birds subjected to in ovo injection of combined arginine and methionine and combined arginine and lysine amino acids. The best survivability was noted in indigenous chickens on in ovo injection of arginine and the combination of arginine and methionine amino acids. In Figure 3, the result showed that the highest cell-mediated immune response of 0.123 $\mathrm{mm}$ was recorded in chicken injected with combined arginine and lysine. This was followed by birds subjected to in ovo injection of arginine $(0.116 \mathrm{~mm})$ and the lowest cell-mediated immune response of $0.054 \mathrm{~mm}$ was obtained in birds on in ovo injection of the combination of arginine and methionine amino acids. Plates 1, 2, 3 and 4 show the effects of in ovo injection of amino acids on duodenal histology of improved indigenous chickens at 7 days of age. In Plate 1, moderate number of duodenal villi were observed with varying heights. Few foci of mild sloughing off of enterocytes are prominent. In Plate 2, there are few tall duodenal villi (red arrow) and the crypts are also high (blue arrow). Plate 3 reveals numerous tall duodenal villi (red arrows) of improved indigenous chickens. Furthermore, the plate shows that enterocytes appear intact without been affected. Moderate congestion of the blood vessels in the lamina propria (green arrow) and crypts are slightly high (blue arrow) and in Plate 4, moderate amounts of short duodenal villi (red arrows) and reduced crypts (blue arrow) are obtained. There is moderate expansion of lamina propria (green arrow). Table 3 shows the effect of in ovo injection of amino acids on blood parameters of indigenous chickens. There were no significant $(\mathrm{P}>0.05)$ differences in all parameters considered.

Table 2: Effect of in ovo administration of amino acids on growth performance of FUNAAB Alpha broiler chickens

\begin{tabular}{|c|c|c|c|c|c|c|}
\hline Parameter & Control & Arginine & $\begin{array}{l}\text { Arginine + } \\
\text { Methionine }\end{array}$ & $\begin{array}{l}\text { Arginine + } \\
\text { Lysine }\end{array}$ & SEM & P-value \\
\hline Initial weight (g/bird) & 84.43 & 79.83 & 78.17 & 76.13 & 2.89 & 0.340 \\
\hline Final weight (g/bird) & 1304.80 & 1414.10 & 1232.70 & 1282.90 & 73.3 & 0.449 \\
\hline $\begin{array}{l}\text { Average weight gain } \\
\text { (g/bird/day) }\end{array}$ & 21.79 & 23.83 & 20.62 & 21.55 & 1.36 & 0.481 \\
\hline $\begin{array}{l}\text { Total weight gain } \\
\text { (g/bird/day) }\end{array}$ & 1220.30 & 1334.30 & 1154.50 & 1206.80 & 76.0 & 0.481 \\
\hline $\begin{array}{l}\text { Average feed intake } \\
\text { (g/bird/day) }\end{array}$ & 50.01 & 52.09 & 61.02 & 67.27 & 3.21 & 0.054 \\
\hline $\begin{array}{l}\text { Total feed intake } \\
\text { (g/bird) }\end{array}$ & 2801.00 & 2917.00 & 3417.00 & 3767.00 & 179.00 & 0.054 \\
\hline $\begin{array}{l}\text { Feed conversion ratio } \\
\text { (FCR) }\end{array}$ & $2.29^{\mathrm{b}}$ & $2.18^{\mathrm{b}}$ & $2.96^{\mathrm{a}}$ & $3.12^{\mathrm{a}}$ & 0.0831 & 0.003 \\
\hline Survivability (\%) & $92.86^{\mathrm{ab}}$ & $100.00^{\mathrm{a}}$ & $100.00^{\mathrm{a}}$ & $70.83^{b}$ & 4.13 & 0.021 \\
\hline
\end{tabular}


Effects of in ovo injection of amino acids on hatching performance, cell-mediated immunity and blood profile

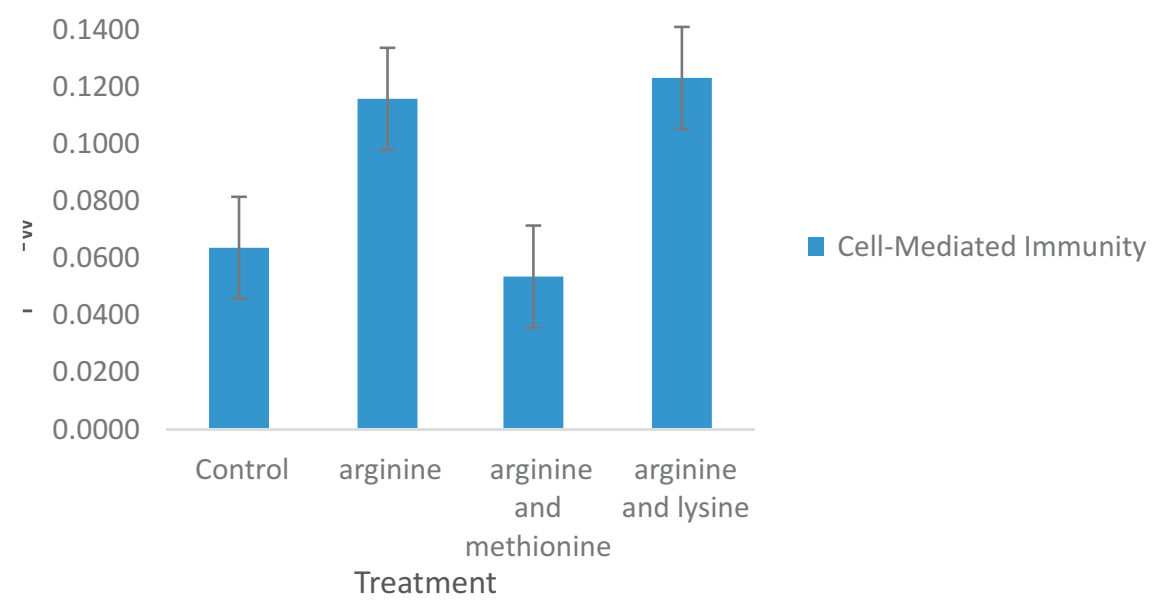

Figure. 3: Effect of in ovo injection of arginine, its combination with methionine and lysine on cell-mediated immunity of FUNAAB Alpha broiler chickens.
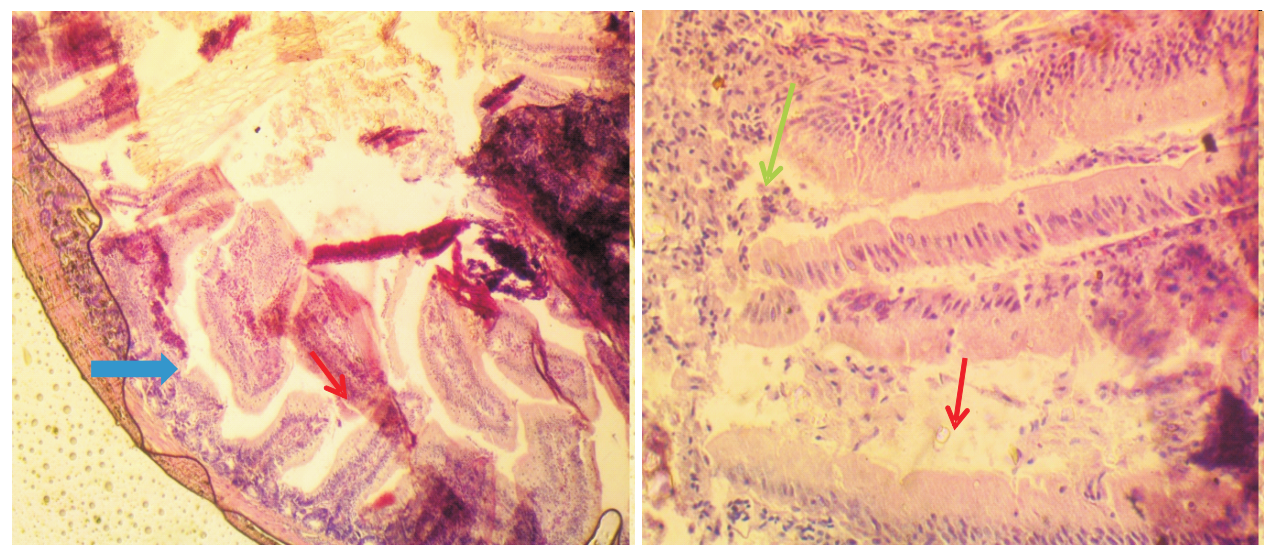

Plate 1: Duodenal histology of FUNAAB Alpha broiler chicken (Control)
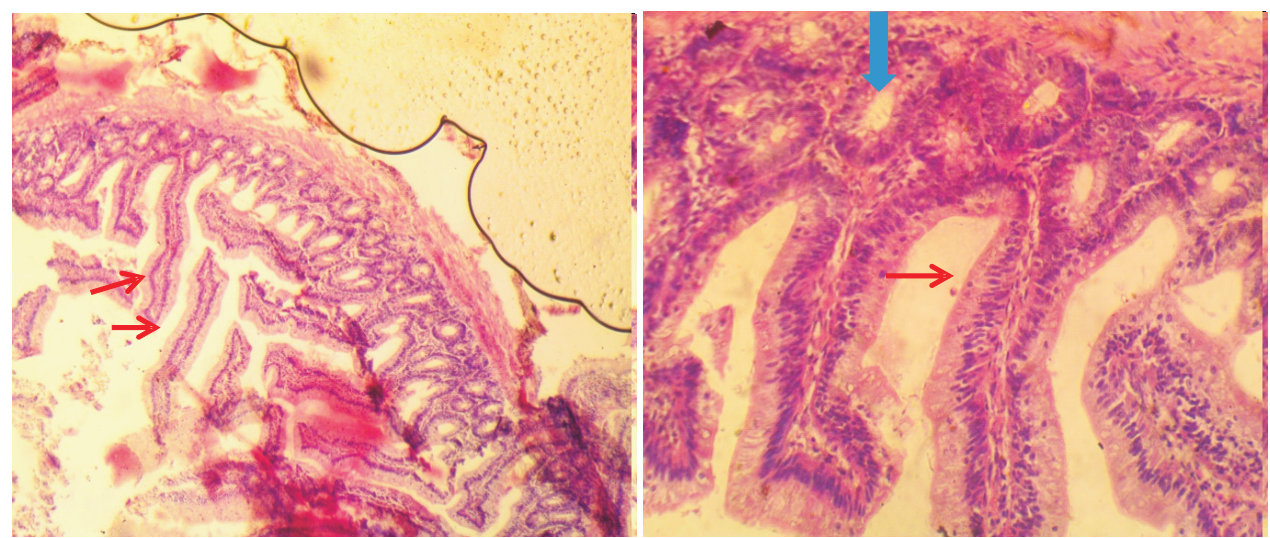

Plate 2: Duodenal histology of FUNAAB Alpha broiler chicken on in ovo injection of Arginine 
Sogunle, Olutayo, Odutayo, Oso, Sobukola, Safiyu and Elangovan
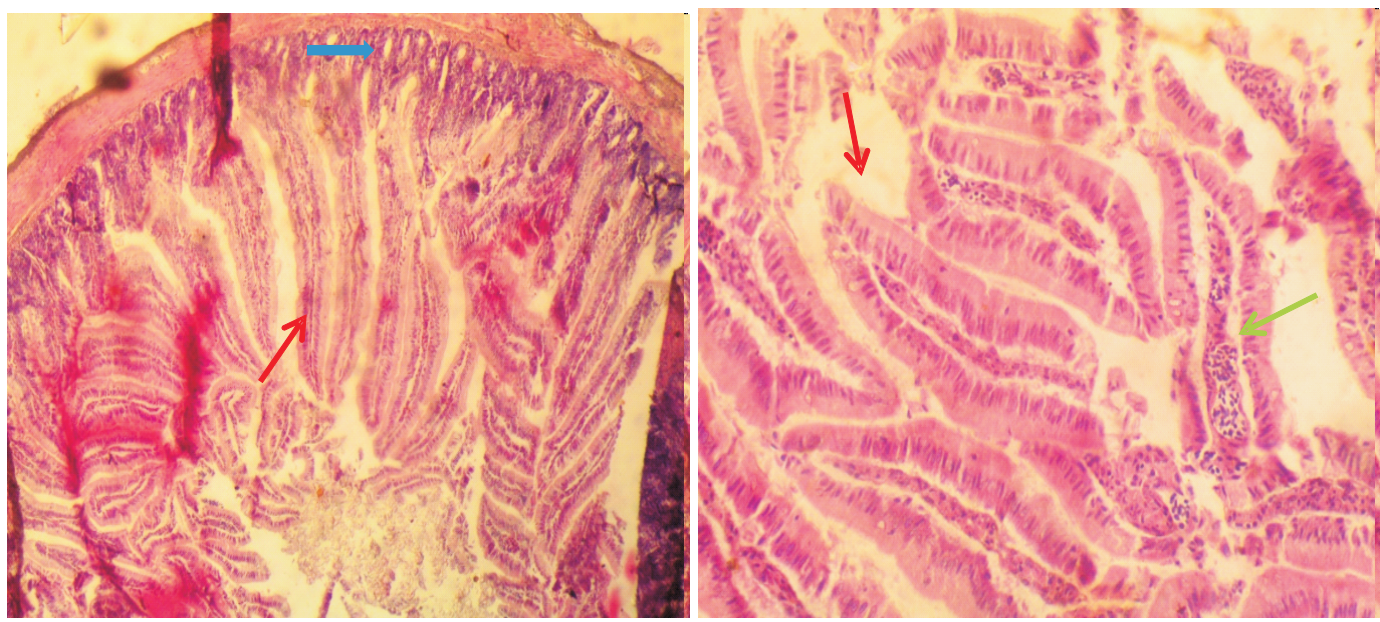

Plate 3: Duodenal histology of FUNAAB Alpha broiler chicken on in ovo injection of the combination of arginine and methionine


Plate 4: Duodenal histology of FUNAAB Alpha broiler chicken on in ovo injection of the combination of arginine and lysine 
Effects of in ovo injection of amino acids on hatching performance, cell-mediated immunity and blood profile

Table 3 : Effect of in ovo administration of amino acid on blood profile of FUNAAB Alpha broiler chickens at $3^{\text {rd }}$ week of age

\begin{tabular}{|c|c|c|c|c|c|c|}
\hline Parameter & Control & Arginine & $\begin{array}{l}\text { Arginine + } \\
\text { Methionine }\end{array}$ & $\begin{array}{l}\text { Arginine } \\
+ \\
\text { Lysine }\end{array}$ & SEM & P-value \\
\hline \multicolumn{7}{|c|}{ Haematological Parameters } \\
\hline Packed cell volume (\%) & 28.00 & 31.00 & 31.00 & 31.50 & 1.70 & 0.286 \\
\hline Haemoglobin $(\mathrm{g} / \mathrm{dl})$ & 9.30 & 10.45 & 10.20 & 10.60 & 0.54 & 0.223 \\
\hline Red blood cell $\left(\times 10^{12} \mathrm{~L}\right)$ & 2.350 & 2.550 & 2.550 & 2.600 & 0.16 & 0.468 \\
\hline $\mathrm{WBC}\left(\times 10^{9} / \mathrm{L}\right)$ & 11.20 & 11.75 & 11.90 & 13.20 & 1.01 & 0.640 \\
\hline Heterophil (\%) & 29.00 & 31.00 & 35.00 & 31.50 & 2.70 & 0.605 \\
\hline Lymphocyte (\%) & 70.00 & 67.50 & 63.50 & 65.50 & 2.40 & 0.398 \\
\hline Eosinophils (\%) & 0.50 & 0.00 & 0.50 & 0.50 & 0.44 & 0.898 \\
\hline Basophil (\%) & 0.50 & 1.00 & 0.00 & 1.00 & 0.31 & 0.275 \\
\hline Monocyte (\%) & 0.00 & 0.50 & 1.00 & 1.50 & 0.38 & 0.142 \\
\hline \multicolumn{7}{|c|}{ Serum biochemical parameters } \\
\hline Total protein $(\mathrm{g} / \mathrm{dl})$ & 4.10 & 4.65 & 5.20 & 3.45 & 0.78 & 0.563 \\
\hline Albumin $(\mathrm{g} / \mathrm{dl})$ & 2.15 & 2.55 & 3.15 & 1.95 & 0.39 & 0.338 \\
\hline Globulin $(\mathrm{g} / \mathrm{dl})$ & 1.95 & 2.10 & 2.05 & 1.50 & 0.43 & 0.757 \\
\hline Cholesterol (mg/dl) & 121.75 & 114.95 & 103.60 & 120.10 & 7.82 & 0.425 \\
\hline Triglyceride (mg/dl) & 123.05 & 119.05 & 90.25 & 104.20 & 8.53 & 0.148 \\
\hline $\begin{array}{l}\text { Alkaline phosphatase } \\
\text { (U/l) }\end{array}$ & 34.00 & 29.00 & 30.50 & 31.00 & 4.98 & 0.886 \\
\hline $\begin{array}{l}\text { Aspartate transaminase } \\
(\mathrm{U} / 1)\end{array}$ & 38.50 & 29.00 & 61.50 & 34.00 & 17.60 & 0.731 \\
\hline $\begin{array}{l}\text { Alanine transaminase } \\
(\mathrm{U} / \mathrm{l})\end{array}$ & 15.00 & 11.50 & 17.50 & 12.50 & 5.23 & 0.832 \\
\hline
\end{tabular}

\section{Discussion}

The results revealed highest hatchability percentage of 70.27 in the control treatment followed by $51.35 \%$ in L-arginine-injected eggs and lowest hatchability percentage of 2.70 in L-methionine-injected eggs. This implies that the injection of methionine did not support the embryonic development unlike arginine which gave a better hatchability (Ohta et al., 2001). However, the low hatchability observed in methionine-injected eggs might be due to the concentration of the amino acid solution used, which leads to late embryonic mortality. Factors such as temperature instability during in ovo procedures and $\mathrm{pH}$ fluctuations in the eggs could also be attributed to the differences obtained in the hatchability of in ovo injected and uninjected eggs. Similarly, low hatchability result was reported by Coskun et al. (2014), when DL-methionine was injected into the fertile broilers eggs compared with the control. The outcomes of the first trial prompted the second trial where L-arginine was then combined with L-methionine as well as L-lysine. From Figure 2, the result showed highest hatchability percentage of 89.58 in the control. Unlike in trial 1, where arginine-injected eggs were next in percentage hatchability to the control, but the eggs injected with combination of arginine and Lysine nutrients recorded 39.29 hatchability. This was followed by those on in ovo injection of arginine and the lowest hatchability $(21.43 \%)$ was recorded on hatching eggs injected with L-arginine and L-methionine combination. Coskun et al. (2014) reported that hatchability decreased when nutrient injected into the 


\section{Sogunle, Olutayo, Odutayo, Oso, Sobukola, Safiyu and Elangovan}

amnion fluid is done with different injection depths. On the other hands, other researchers (Uni et al., 2005; Bottje et al., 2010; Chamani et al., 2012) signified that in ovo injection depths did not affect hatchability. Moreover, nutrients used for in ovo injection is an important factor for embryonic development and hatching performance. From the two trials in this study, it could be confirmed that embryogenesis process is aided by in ovo injection of L-arginine nutrient (Al-Daraji et al., 2012). Birds from eggs on in ovo injection of arginine had the best feed conversion ratio of 2.18 which is comparable to the value obtained in birds from eggs on in ovo injection of the combination of L-arginine and Lmethionine (2.96) and those on the combination of arginine and lysine (3.12). This was corroborated by the finding of AlDaraji et al. (2012). Survivability improved in chickens from eggs on in ovo injection of L-arginine and the combination of Larginine and L-methionine thereby confirming the relative importance of the in ovo technique in boosting the bird's health (Sogunle et al., 2018).

Figure 3 revealed that chickens on in ovo injection of combined L-arginine and Llysine had the highest cell-mediated immune response of 0.123 , followed by those on L-arginine injection (0.116) and the least cell-mediated immune response (0.054) was from birds on the combination of L-arginine and L-methionine. The importance of amino acids to immunity has become apparent in recent years particularly in studies (Bilsborough, 2002; Brandtzaeg, 2009; 2011) which demonstrate not only the importance of Gut-Associated Lymphoid Tissue (GALT) and examine the immunomodulatory effects of specific amino acids on immunity. It has been recently reported (Wu et al., 1991) that T-cells, B-cells dendritic cells and macrophages express glutamate receptors (Sturgill et al., 2011) suggesting that glutamate likely has an important role in immune cell function. Wu et al. (2010) reported that the immune system is particularly sensitive to changes in arginine availability during early development. Birds have different levels of immune response to diverse external forces which was observed in this study. At day 7 in trial 2, effect of in ovo injection of amino acids on duodenal histology of indigenous shown in Plates 1, 2, 3 and 4 indicated variations in thickness and length of gastro intestinal tract and increase length of the villi in duodenum. In ovo injection of L-arginine showed the presence of few tall duodenal villi (red arrow in Plate 2). Also, duodenum of indigenous chicken on in ovo injection of the combination of arginine and methionine revealed several tall of villi and crypts which are slightly high. Meanwhile, that of control showed moderate amount of duodenal villi presence. Hu et al. (2013) reported dietary sources of amino acids were reported to influence villus height, villus width, crypt depth and mucosal thickness in gross histology of the intestine. In ovo feeding of amino acids may have been responsible for the development of gastro-intestinal tract of indigenous chicken in this study. Zhan et al. (2008) has earlier reported that dietary L-arginine supplementation supports the growth and development of the intestine and mucosal barrier in weanling piglets. Although, AlDaraji et al. (2012) reported significant differences in the blood metabolites of chickens on in ovo injection of amino acids, this study showed no differences in the blood parameters determined.

\section{Conclusion}

The in ovo injection of the amino acids enhanced the gastrointestinal development of the FUNAAB-Alpha chicken. In addition, in ovo injection of L-arginine either singly or in combination with 1- 
methionine or 1-lysine improved hatchability.

\section{Acknowledgement}

The authors are grateful to the World Bank Centre of Excellence in Agriculture Development and Sustainable Environment, Federal University of Agriculture, Abeokuta for the grants-in-aid provided for the study. The College of Animal Science and Livestock Production, Federal University of Agriculture, Abeokuta is also appreciated for the provision of equipment and materials for the field study.

\section{References}

Al-Daraji, H. J., Al-Mashadani, A. A., AlHayani, W. K., Al-Hassani, A. S. and Mirza, H. A. 2012. Effect of in ovo injection with L-arginine on productive and physiological traits of Japanese quail. South African Journal of Animal Science, 42:139145.

Althnaian, T. A., Alkhadair, K. M., Albakhadam, I. F., Abdelhay, M. Ali, Homeda, A. M. and El-Bahr, S. M. 2013. Histological and Histochemical Investigation on duodenum of Dromedary Camels (Camelus dromedaries). Science International, 1(6): 217-221.

Atakisi, O., Atakisi, E. and Kart, A. 2009. Effects of dietary zinc and Larginine supplementation on total antioxidants capacity, lipid peroxidation, nitric oxide, egg weight, and blood biochemical values in Japanese quails. Biological Trace Element Research, 132 (1-3) 136.

Bhanja, S. K., Agarwal, A. B. and Majumdar, S. 2012. Modulation of post-hatch growth and immunocompetence through in ovo injection of limiting amino acids in broiler chickens. Indian Journal of Animal Science 82: 993-998.

Bhanja, S. K., Mandal, A. B. and Johri, T. S. 2004. Standardisation of injection sites, needle length, embryonic age and concentration of amino acids for in ovo injected in broiler breeder eggs. Indian Journal of Animal Science, 39:105-111.

Bilsborough, J. and Viney, J. L. 2002. Getting to the guts of immune regulation. Immunology, 106:139143.

Bottje, W., Wolfenden, A., Ding, L., Wolfenden, R., Morgan, M., Pumford, N., Lassiter, K., Duncan, G., Smith, T., Slagle, T. and Hargis, B. 2010. Improved hatchability and post-hatch performance in turkey poults receiving a dextrin-iodinated casein solution in ovo. Poultry Science, 89:2646-2650.

Brandtzaeg, P. 2009. Mucosal immunity: induction, dissemination, and effector functions. Scandinavian Journal of Immunology, 70: 505515.

Brandtzaeg, P. 2011. The gut as c om municator between environment and host: immunological consequences. European Journal of Pharmacology, 668 (Suppl 1): 516532.

Chamani, M., Tasharrofi, S., Forudi, F., Sadeghi, A. A. and Aminafshar, M., 2012. Evaluating the effects of in ovo Injection of Different Nutrients on Hatch Percentage, Performance and Carcass Parameters of Broilers. Annals of Biological Research, 3 (7), 37713776.

Corrier, D.E. and Deloach, J.R. 1990. Evaluation of cell-mediated, 
cutaneous basophilic hypersensitivity in young chickens by an inter-digital skin test. Poultry Science, vol. 69. 1990, p. 403-408.

Coskun, I., Erener, G., Sahin, A., Karadavut, U., Altop, A., Okur, A.A. 2014. Impacts of in ovo feeding of DL-Methionine on Hatchability and Chick Weight. Turkish Journal of Agriculture Food Science and Technology, 2(1), 47-50.

Gore, A. B. and Qureshi, M. A. 1997. Enhancement of humoral and cellular immunity by vitamin $\mathrm{E}$ after embryonic exposure. Poultry Science 76:984-991.

Hajihosaini. M. and Mottaghitalab, M. 2004. Effect of amino acid injection in breeder eggs on hatchability and growth of hatched chicken. Journal of Agricultural Science, 1:23-32.

Hu, C. H., Qian, Z. C., Song, J., Luan, Z. S., and Zuo, A. Y. 2013. Effects of zinc oxide-montmorillonite hybrid on growth performance, intestinal structure and function of broiler chicken. Poultry Science, 92: 143150.

Khajali, F. and Wideman R. F. 2010. Dietary arginine; metabolic, environmental, immunological and physiological interrelationships. World's Poultry Science Journal. 66; 751-766.

Maatman, R., Gross, W. B., Dunnington, E. A., Larsen, A. S. and Siegel, P. B. 1993. Growth immune response and behaviour of broiler and leghorn cockerels fed different methionine levels. Archieve Geflugelkunde, 57: 249-256.

Minitab 17 Statistical Software. 2013. Stable release 17.1.0 (Computer software). State College, PA: Minitab, Inc. (www.minitab.com)
Ohta, Y., Kidd, M. T. and Ishibashi, T. 2001. Embryo growth and amino acid concentration profiles of broiler breeder eggs, embryos and chicks after in ovo administration of amino acids. Poultry Science 80: 1430-36.

Safaei, A., Khesht, F. A., Froudi, F., Abedini, M. R. and Rahanjam, S. M. 2012. Effect of dietary supplementation levels of methionine in broilers diet on immune system and performance. Poultry Science, 91 (Suppl 1) 110.

Safalaoh, A. C. L. 2001. Village Chicken Upgrading Programme in Malawi. World's Poultry Science Journal, 57: 179-188

Schuttle, J. B., Smink, W. and Pack, M. 1997. Requirement of young broiler chicks for glycine and serine. Arch Geflugelkd.61:43-47.

Selim, Sh. A., Gaafar, K. M. and El-ballal, S.S 2012. Influence of in ovo administration with vitamin $\mathrm{E}$ and ascorbic acid on the performance of Muscovy ducks. Emirate Journal of Food Agriculture, 24 (3): 264-271.

Sharma, J. and Burmester, B. 1982. Resistance of Marek's disease at hatching in chickens vaccinated as embryos with the herpes virus. Avian Diseases 26; 134-149

Sogunle, O. M., Elangovan, A. V., David, C. G., Ghosh, J. and Awachat, V. B. 2018. Response of broiler chickens to in ovo administration of inorganic salts of Zinc, Selenium and Copper or their combination. Slovak Journal of Animal Science, 51 (1): 8-19.

Sood, R. 2016. Medical Laboratory Technology and Interpretations. Sixth edition. Jaypee Brothers Medical Publishers Ltd. New Delhi, India.

Sturgill, J. L., Matthews, J., Scherle, P. and Conrad, D. H. 2011. Glutamate 
signalling through the kainite receptor enhances human immunoglobulin production. Journal of Neuroimmunology, 233: 80-89.

Tako, E., Ferket, P. R. and Uni, Z. 2004. Effects of in ovo feeding of carbohydrates and beta-hydroxybeta-methylbutyrate on the development of chicken intestine. Poultry Science, 83:2023-2028.

Uni, Z., Ferket, P. R., Tako, E. and Kedar, O. 2005. In ovo feeding Improves energy status of the late-term chicken embryos. Poultry Science 84: 764-70.

Wu, G. Y., Field, C. I. and Marliss, E. B. 1991. Elevated glutamine metabolism in splenocytes from spontaneously diabetic BB rats. Biochemistry Journal, 274 (Pt. 1): 49-54.
Wu, X., Ruan, Z., Gao, Y., ., Zhou, X., Wang, L., Geng, M., Hou, Y. and W u, G. 2010 . D i e t a r y supplementation with L-arginine or $\mathrm{N}$-carbamylglutamate enhances intestinal growth and heat shock protein-70 expression in weanling pigs fed a corn- and soybean mealbased diet. Amino acids, 39: 831839.

Zhan, Z., Ou, D., Piao, X., Kim, S. W., Liu, Y. and Wang, J. 2008. Dietary arginine supplementation affects microvascular development in the small intestine of early-weaned pigs. Journal of Nutrition, 138: 1304-1309.

Received: $5^{\text {th }}$ August, 2019

Accepted: $19^{\text {th }}$ December, 2019 